\title{
Rabbit Sucrase-Isomaltase Contains a Functional Intestinal Receptor for Clostridium difficile Toxin A
}

\author{
Charalabos Pothoulakis, Richard J. Gilbert, ${ }^{\ddagger}$ Christos Cladaras, Ignazio Castagliuolo, Giorgio Semenza, \\ J. Scott Montcrief, ${ }^{\S}$ Joanne Linevsky, Ciaran P. Kelly, Sigfus Nikulasson, ${ }^{*}$ Himanshu P. Desai, $\|$ Tracy D. Wilkins, ${ }^{\S}$ \\ and J. Thomas LaMont \\ Sections of Gastroenterology and Molecular Genetics, and *Department of Pathology, Evans Memorial Department of Clinical Research, \\ Boston University School of Medicine, Boston, Massachusetts; ${ }^{\ddagger}$ Section of Gastroenterology, St. Elizabeth Hospital, Boston, \\ Massachusetts; ${ }^{\S}$ Department of Anaerobic Microbiology, Virginia Polytechnic Institute, Blacksburg, Virginia; $"$ Division of \\ Gastroenterology and Nutrition, Winthrop-University Hospital, Mineola, New York; and State University of New York at Stony Brook, \\ New York; and ${ }^{\mathbb{I}}$ Department of Biochemistry, Swiss Federal Institute of Technology, Zurich, Switzerland
}

\section{Abstract}

The intestinal effects of Clostridium difficile toxin A are initiated by toxin binding to luminal enterocyte receptors. We reported previously that the rabbit ileal brush border (BB) receptor is a glycoprotein with an $\alpha$-d-galactose containing trisaccharide in the toxin-binding domain (1991. J. Clin. Invest. 88:119-125). In this study we characterized the rabbit ileal BB receptor for this toxin. Purified toxin receptor peptides of 19 and 24 amino acids showed $100 \%$ homology with rabbit sucrase-isomaltase (SI). Guinea pig receptor antiserum reacted in Western blots with rabbit SI and with the purified toxin receptor. Antireceptor IgG blocked in vitro binding of toxin A to rabbit ileal villus cell BB. Furthermore, anti-SI IgG inhibited toxin A-induced secretion (by $78.1 \%, P<0.01$ ), intestinal permeability (by $80.8 \%, P<$ $0.01)$, and histologic injury $(P<0.01)$ in rabbit ileal loops in vivo. Chinese hamster ovary cells transfected with SI cDNA showed increased intracellular calcium increase in response to native toxin (holotoxin) or to a recombinant 873-amino acid peptide representing the receptor binding domain of toxin A. These data suggest that toxin A binds specifically to carbohydrate domains on rabbit ileal SI, and that such binding is relevant to signal transduction mechanisms that mediate in vitro and in vivo toxicity. (J. Clin. Invest. 1996. 98:641-649.) Key words: Clostridium difficile • enterotoxin • toxin receptor $\bullet$ sucrase-isomaltase $\bullet$ lectin binding

\section{Introduction}

Toxigenic strains of Clostridium difficile are the major cause of antibiotic-associated colitis in humans and animals (1).C. difficile produces two protein exotoxins: toxin $\mathrm{A}$, an enterotoxin which also possesses mild cytotoxic activity, and toxin B, a cytotoxin which does not elicit enterotoxicity in animals $(2,3)$. Experiments in our laboratory (3) and elsewhere $(2,4)$ indicate that the primary pathogenic factor in $C$. difficile-associ-

Address correspondence to Charalabos Pothoulakis, M.D., Division of Gastroenterology, Dana 501, Beth Israel Hospital, 330 Brookline Avenue, Boston, MA 02215. Phone: 617-667-1259; FAX: 617-667-2767.

Received for publication 3 November 1995 and accepted in revised form 9 May 1996.

J. Clin. Invest.

(C) The American Society for Clinical Investigation, Inc.

0021-9738/96/08/0641/09 \$2.00

Volume 98, Number 3, August 1996, 641-649 ated disease in experimental animals is toxin $\mathrm{A}$, a $308-\mathrm{kD}$ protein (5) which inactivates the intracellular GTP binding proteins Rho A and B $(6,7)$. Sequence analysis of toxin A (5) indicates that the receptor binding domain resides in a series of tandem repeats which occupy the carboxyl-terminal 868 amino acids, or approximately one-third of the molecule. A necessary first step for enterotoxicity is binding of toxin A to luminal enterocyte receptors. For example, a monoclonal antibody directed against this binding domain of toxin A blocks the enterotoxic activity of toxin $\mathrm{A}$ in mouse intestine by inhibiting toxin binding to its receptor (8). Moreover, vaccination of hamsters with a recombinant peptide from the receptor binding portion of toxin A protects against $C$. difficile (9).

Specific receptor binding activity for toxin A has been demonstrated on rabbit, hamster, and human enterocyte membranes (10-13) as well as on rabbit erythrocytes (14) and neutrophils (15), but thus far these receptors have not been identified. A single class of toxin A glycoprotein receptors on rabbit intestinal brush border $(\mathrm{BB})^{1}$ appears to be linked to a pertussis toxin-sensitive $\mathrm{G}$ protein(s) (10). We also observed that toxin A receptor binding activity is not expressed in newborn rabbit BB but slowly increases after weaning to adult levels (16), a phenomenon which might explain the low level of biologic responsiveness of newborn rabbit intestine to toxin A (16).

The purpose of this study was to characterize the toxin A membrane receptor from rabbit ileal BB. Our purification strategy was based on prior reports that toxin A interacted with its receptor via lectin-like binding to a specific trisaccharide $\operatorname{Gal} \alpha_{1-3} \operatorname{Gal}_{1-4} \operatorname{GlcNAc}(11,14)$. The plant lectin BS-1 derived from the seeds of Bandeirea simplicifolia also binds specifically to glycoconjugates bearing terminal $\alpha$-D-galactose residues (11). Using a BS-1 lectin affinity column and a toxin A affinity column we were able to partially purify and identify a specific toxin A binding glycoprotein on rabbit $\mathrm{BB}$. We report here that the rabbit ileal BB exoenzyme sucrase-isomaltase (SI), a complex of sucrose $\alpha$-D-glucohydrolase, EC 3. 2. 1. 48, and isomaltase, EC 3.2.1. 10, specifically binds toxin A on its carbohydrate side chains and mediates toxin-related effects in cultured cells and in rabbit intestine in vivo.

\section{Methods}

Toxin purification and radiolabeling. Toxin A was purified from culture supernatants of $C$. difficile strain 10463 and tritiated and biotinylated as described previously $(10,16)$. Enterotoxicity of labeled and

1. Abbreviations used in this paper: $\mathrm{BB}$, brush border; $\mathrm{CHO}$, Chinese hamster ovary; SI, sucrase-isomaltase; WGA, wheat germ agglutinin. 
unlabeled toxin A preparations was determined in rat and rabbit intestinal loops $(15,17-20)$. Stock solutions of purified toxin A contained between 400 and $1,400 \mu \mathrm{g} / \mathrm{ml}$ protein as measured by the bicinchoninic acid protein assay reagent (Pierce Laboratories, Rockford, IL).

Expression and purification of recombinant toxin A carboxyl-terminal peptides. Plasmid pCDtoxA.03, containing the $C$. difficile toxin A gene (21), was digested with Sau3A, and the resulting restriction fragments were separated by electrophoresis in $1 \%$ agarose. An $\sim 3.5$-kb restriction fragment was excised and purified from the agarose gel using Sephaglas Prep Kit (Pharmacia Biotech, Piscataway, $\mathrm{NJ}$ ). This fragment contained the carboxyl-terminal 2,604 bp of the toxin A gene encoding the entire carbohydrate binding repeating unit of toxin A as well as five upstream amino acids. The $3^{\prime}$ recessed ends were filled in using exonuclease-free Klenow fragment (United States Biochemical Corp., Cleveland, $\mathrm{OH}$ ), and the toxin A gene fragment was subcloned at the SmaI site of the glutathione $S$-transferase expression vector pGEX-3X (Pharmacia Biotech). A recombinant plasmid containing the fragment in the correct orientation for expression was determined by restriction analysis and designated p3X-ARU. Escherichia coli DH5 $\alpha$ harboring p3X-ARU was grown in 1 liter of Terrific Broth (22) containing $0.1 \mathrm{mg} / \mathrm{ml}$ of ampicillin to an optical density of 0.6 at $600 \mathrm{~nm}$. Recombinant protein expression was then induced by addition of isopropyl- $\beta$-D-thiogalactosidase to a final concentration of $1 \mathrm{mM}$. After $5 \mathrm{~h}$, cells were pelleted by centrifugation and suspended in $20 \mathrm{ml}$ of phosphate-buffered saline, $\mathrm{pH}$ 7.4. Cells were disrupted by sonication, and cellular debris was removed by centrifugation. Lysates were filtered through $0.45 \mu \mathrm{m}$ pore size membranes. The recombinant glutathione $S$-transferase fusion protein containing the receptor binding domain of toxin A was purified from lysates by affinity chromatography with glutathione-Sepharose 4B.

Purity of the recombinant peptide was analyzed by SDS-PAGE, using the discontinuous system of Laemmli (23). The purified peptide contained the toxin A repeating units as determined by immunoblot analysis using the monoclonal antibody PCG-4 (24).

Toxin A affinity column. Toxin A-Sepharose was prepared by coupling activated $\mathrm{CH}-\mathrm{Sepharose} 4 \mathrm{~B}$ (Pharmacia Biotech) to purified toxin A. Briefly, 1 gram of CH-Sepharose was first suspended in $200 \mathrm{ml}$ of $1 \mathrm{mM} \mathrm{HCl}$ for $15 \mathrm{~min}$, then centrifuged $(1,000 \mathrm{~g} \times 10 \mathrm{~min}$ at $\left.4^{\circ} \mathrm{C}\right)$ and suspended in $3 \mathrm{ml}$ of bicarbonate buffer $\left(0.1 \mathrm{M} \mathrm{NaHCO}_{3}\right.$, $0.5 \mathrm{M} \mathrm{NaCl}, \mathrm{pH} 8.0) .3 \mathrm{ml}(0.5-1 \mathrm{mg} / \mathrm{ml})$ of purified toxin A was dialyzed against bicarbonate buffer $(1$ liter $\times 24 \mathrm{~h})$ and incubated with the Sepharose suspension for $16 \mathrm{~h}$ at $4^{\circ} \mathrm{C}$. The toxin A-Sepharose mixture was introduced into a $1 \times 2$-cm glass column, washed with bicarbonate buffer, and any remaining active groups were blocked by washing with $0.1 \mathrm{M}$ Tris- $\mathrm{HCl}$ buffer $(\mathrm{pH} \mathrm{8.0)}$ for $1 \mathrm{~h}$. The column was washed twice with $0.1 \mathrm{M}$ sodium acetate buffer containing $0.5 \mathrm{M}$ $\mathrm{NaCl}(\mathrm{pH} 6.0)$ and $0.1 \mathrm{M}$ Tris- $\mathrm{HCl}$ buffer containing $0.5 \mathrm{M} \mathrm{NaCl}$ before use.

Receptor purification. Rabbit ileal BB membranes were solubilized in 2\% CHAPS (3-[cholamidopropyl dimethylammoniol]-1-propanesulfonate; Pierce Laboratories) as previously described (10). All purification steps were performed at $4^{\circ} \mathrm{C}$ using a working buffer of 10 $\mathrm{mM}$ Tris ( $\mathrm{pH}$ 7.4) containing 0.2\% CHAPS. Solubilized BB (50-100 $\mathrm{mg}$ ) were loaded onto a $10 \times 2-\mathrm{cm}$ B. simplicifolia (BS-1) Sepharose column (10 ml) (E-Y Laboratories, Inc., San Mateo, CA) equilibrated with working buffer. The column was washed with $40 \mathrm{ml}$ of working buffer and $30 \mathrm{ml}$ of buffer containing $0.3 \mathrm{M} \mathrm{NaCl}$ to remove unbound BB proteins. Proteins containing $\alpha$-D-galactose were specifically eluted with buffer containing $0.2 \mathrm{M}$ of $\alpha$-D-galactose. ${ }^{3} \mathrm{H}$-Toxin A binding activity of eluted proteins was measured by immobilization of solubilized receptor proteins on wheat germ agglutinin (WGA)lectin-agarose (E-Y Laboratories, Inc.) as described previously by us (10). The fraction with the highest toxin A binding activity from the BS-1 column was then further purified on the toxin A affinity gel (see above). Final toxin A receptor purification was achieved by HPLC on a $7.5 \mathrm{~mm} \times 30 \mathrm{~cm}$ G400 SW molecular sieve column (Phenomenex Inc., Torrance, CA). Affinity-purified receptor $(0.2 \mathrm{ml})$ was injected into the column which was then eluted at $1 \mathrm{ml} / \mathrm{min}$ with $10 \mathrm{mM}$ Tris buffer containing $0.2 \%$ CHAPS. 1-ml fractions were monitored for protein by absorbance at $230 \mathrm{~nm}$ and for ${ }^{3} \mathrm{H}$-toxin A binding activity by the WGA-agarose soluble binding assay (10). SDS gel electrophoresis of the purified receptor was performed as described by Laemmli (23) on $7.5 \%$ separating slab gels, $1 \mathrm{~mm}$ in thickness.

${ }^{3} H$-Toxin A binding to solubilized BB receptor. Binding of ${ }^{3} \mathrm{H}$-toxin A to solubilized receptor fractions immobilized on WGA-agarose was measured as described previously (10). The apparent dissociation constant of binding $\left(K_{\mathrm{d}}\right)$ was calculated by Scatchard plot analysis using the program "Ligand" as described by Munson (25). In some experiments purified SI (50 ng-10 $\mu \mathrm{g}$ ) was absorbed to WGA-agarose and ${ }^{3} \mathrm{H}$-toxin $\mathrm{A}$ binding was then estimated (10). In another series of experiments purified SI $(5 \mu \mathrm{g})$ was preincubated $\left(37^{\circ} \mathrm{C}\right)$ for $0-8 \mathrm{~h}$ with $0.5 \mathrm{U}$ of $\alpha$-galactosidase (Sigma Immunochemicals, St. Louis, $\mathrm{MO})$ in $0.4 \mathrm{ml}$ of $10 \mathrm{mM}$ Tris buffer $(\mathrm{pH} \mathrm{7.4)}$ or buffer alone $(8 \mathrm{~h}$, control). The mixture was then absorbed to WGA-agarose and ${ }^{3} \mathrm{H}$-toxin A specific binding was then estimated (10). Two such experiments were performed, with triplicate determinations per time point.

Amino acid sequencing of receptor tryptic peptides. $20 \mu \mathrm{g}$ of the toxin A affinity-purified receptor was electrophoresed onto a $7.5 \%$ SDS-polyacrylamide gel and the proteins were electroblotted onto a nitrocellulose membrane (Schleicher \& Schuell, Inc., Keene, NH). The membrane was immersed for $60 \mathrm{~s}$ in $0.1 \%$ Ponceau S dye (Sigma Immunochemicals) in $1 \%$ acetic acid. Excess stain was removed by washing the membrane in $1 \%$ acetic acid for 1-2 min, and the major protein band containing the toxin A binding activity at between 120 and $140 \mathrm{kD}$ was excised, transferred to an Eppendorf tube, and destained by washing with $200 \mu \mathrm{M} \mathrm{NaOH}$ and distilled water. The nitrocellulose membrane was then incubated $\left(30 \mathrm{~min}\right.$ at $\left.37^{\circ} \mathrm{C}\right)$ in $1.2 \mathrm{ml}$ of polyvinylpyrrolidone (PVP-40; Sigma Immunochemicals) dissolved in $100 \mathrm{mM}$ acetic acid followed by extensive washing with distilled water. The membrane was then cut into small $(1 \mathrm{~mm} \times 1 \mathrm{~mm})$ pieces which were incubated in situ with trypsin (Worthington Biochemical Corp., Freehold, NJ) in $0.2 \mathrm{ml}$ of $100 \mathrm{mM} \mathrm{NaHCO}$ buffer (pH 8.2) for $16 \mathrm{~h}$ at $37^{\circ} \mathrm{C}$. Eluted tryptic peptides were immediately loaded onto an HPLC C18 reverse-phase column (VYDAC, Hesperia, CA) that was acidified with $10 \mu \mathrm{l}$ of trifluoroacetic acid (TFA; Pierce Laboratories) $/ \mathrm{H}_{2} \mathrm{O}$ 10:90 (vol/vol). Tryptic fragments were eluted with a linear gradient of $0.1 \%$ TFA in double distilled water to $0.09 \%$ TFA in acetonitrile at $0.1 \mathrm{ml} / \mathrm{min}$. $1-\mathrm{ml}$ fractions were monitored for protein by optical density at $215 \mathrm{~nm}$. Amino acid sequences of peptides were determined with a protein sequencer (model 477A; Applied Biosystems, Inc., Foster City, CA) with a 120A on-line PTA-AA Analyzer.

Receptor antibodies. Adult male guinea pigs (Charles River Breeding Laboratories, Wilmington, MA) were immunized with the 120-140-kD toxin A receptor BB protein eluted from SDS-PAGE of the toxin A affinity column-purified receptor $(10 \mu \mathrm{g})$. A $250-\mu \mathrm{l}$ aliquot of the eluted receptor protein was then mixed 1:1 with adjuvant (Ribi Adjuvant System; Ribi ImmunoChem Research, Inc., Hamilton, MT) in distilled water following the manufacturer's recommendations. Animals were injected both subcutaneously $(0.4 \mathrm{ml})$ and intraperitoneally $(0.1 \mathrm{ml})$ with the receptor-adjuvant mixtures every $2 \mathrm{wk}$ for $4 \mathrm{wk}$, and then every month for 2 mo. Two guinea pigs were immunized with vehicle plus adjuvant alone (control). Sera were collected $7 \mathrm{~d}$ after the last two injections and the IgG fraction was purified on a Protein A-Sepharose column (Pharmacia Biotech). Two other guinea pigs were immunized with $0.5 \mathrm{mg}$ each of rabbit ileal SI purified by the method of Hunziker et al. (26). Pooled sera from both animals in each group were used in all experiments.

Western blotting of the toxin A receptor and purified SI with antireceptor antibodies. Toxin A BB receptor $(0.5 \mu \mathrm{g})$ purified by toxin A affinity chromatography or purified SI were subjected to $7.5 \%$ SDSPAGE, transferred to nitrocellulose sheets, and a Western blot was performed using antireceptor IgG or control guinea pig IgG.

Effect of antireceptor $\operatorname{Ig} G$ on binding of biotinylated toxin $A$ to rabbit ileum. Binding of biotinylated toxin A to rabbit ileum was determined on $5-\mu \mathrm{m}$ sections of formalin-fixed, paraffin-embedded il- 
Table I. Purification of Toxin A Receptor from Rabbit Ileal $B B$

\begin{tabular}{lccc}
\hline \multicolumn{1}{c}{ Step } & Total protein* & Specific activity & Purification \\
\hline & $m g$ & pmol $^{3}$ H-toxin $/ m g$ & fold \\
Native BB & 320 & 0.3 & 1 \\
Solubilized BB & 115 & 0.3 & 1.1 \\
BS-1 affinity & 3.4 & 13.6 & 45.3 \\
Toxin A affinity & 0.1 & 41.9 & 140 \\
HPLC (fraction 7) & 0.06 & 47.9 & 160 \\
& & & \\
\hline
\end{tabular}

*Protein was estimated by the BCA method (see Methods).

eum of normal 80-d-old rabbits using previously described methods (16). Slides were incubated with either anti-toxin A receptor antibody or control antibody $(50-200 \mu \mathrm{g} / \mathrm{ml})$ for $1 \mathrm{~h}$ followed by three washes with PBS. Biotinylated toxin A $(200 \mu \mathrm{g} / \mathrm{ml})$ was then added for $1 \mathrm{~h}$ followed by three washes with PBS followed by the addition of streptavidin-peroxidase $(10 \mu \mathrm{g} / \mathrm{ml})$ (Sigma Immunochemicals) for 30 min. Control positive slides were made by incubating biotinylated toxin A with normal rabbit ileum, and control negative slides were made by using nonbiotinylated toxin A to normal rabbit ileum. Slides were examined by a histopathologist (H.P. Desai) who was unaware of the antibody used.

Effect of anti-SI antibodies on toxin A-mediated enterotoxicity in rabbit ileal loops. Ileal loops were constructed in fasting anesthetized New Zealand rabbits (two 10-cm loops per animal) (Hare-Marland Laboratories, Hewit, NJ) as described previously by us $(15,17)$. Before injection of loops, both renal pedicles were tied and a bolus of ${ }^{3} \mathrm{H}$-mannitol $(100 \mu \mathrm{Ci})$ was injected intravenously. Loops were then injected with purified toxin A $(20 \mu \mathrm{g})$ in $1 \mathrm{ml}$ of $50 \mathrm{mM}$ Tris buffer ( $\mathrm{pH}$ 7.4) or $1 \mathrm{ml}$ of buffer alone. In some animals ileal loops were first injected with either guinea pig anti-SI polyclonal IgG (1 mg/loop) or the same amount of control guinea pig IgG 15 min before toxin A administration. We measured fluid secretion at $5 \mathrm{~h}$ as loop weight to length ratio $(\mathrm{mg} / \mathrm{cm})$ and intestinal mucosal permeability by dpm of ${ }^{3} \mathrm{H}$-mannitol in luminal fluid ( $\mathrm{dpm} / \mathrm{cm}$ loop). Full thickness ileal tissue samples were fixed in formalin, paraffin embedded, and sections were stained with hematoxylin and eosin. Coded sections were examined and graded for (1) epithelial cell damage, (2) congestion and edema of the mucosa, and (3) neutrophil margination and tissue inflammation. A score of $0-3$, denoting increasingly severe abnormality was assigned to each of these three parameters as described previously (15, 19). An overall histologic score was obtained by adding the individual scores for each of the three parameters.

Cell transfections. The cDNA clone for SI (kindly provided by Dr. Walter Hunziker, Department of Biochemistry, Swiss Federal Institute of Technology, Zurich, Switzerland) was cloned into the expression vector pcDNA1-amp (Invitrogen, San Diego, CA). Chinese hamster ovary $(\mathrm{CHO})$ cells were grown in DMEM with $10 \%$ FCS in a humidified $\mathrm{CO}_{2}$ atmosphere. To generate permanent cell lines 50$60 \%$ confluent $60-\mathrm{mm}$ dishes were transfected using the calciumphosphate DNA coprecipitation method (27). The transfection mixture contained $16 \mu \mathrm{g}$ of plasmid DNA (pcDNA-SI) and $1 \mu \mathrm{g}$ of pRSV-hygroplasmid which confers resistance to hygromycin D (28, 29). Plasmid pRSV-hygro contains the hygromycin B phosphotransferase gene (30) upstream of the Rous sarcoma virus promoter. After $48 \mathrm{~h}$ of incubation at $37^{\circ} \mathrm{C}$ the cultures were split $1: 5$ and plated in DMEM medium supplemented with $10 \%$ FCS and $500 \mu \mathrm{g} / \mathrm{ml}$ hygromycin B. Cells were refed every $3 \mathrm{~d}$ until discrete colonies resistant to hygromycin B appeared. Isolated colonies collected using cloning cylinders were grown to confluency and further characterized for production of SI by Northern blot analysis and SI enzymatic activity. For Northern analysis RNA was prepared by the method of Chomczynski and Sacchi (31) and was electrophoresed on 1\% agarose-formaldehyde gel blotted onto nitrocellulose and hybridized with a uniformly labeled rabbit SI cDNA probe. SI enzymatic activity was estimated by the method of Dahlqvist (32). Briefly, cells were washed twice with ice-cold PBS and then scraped off the culture dishes with a rubber policeman, and centrifuged at $11,000 \mathrm{~g}$ for $5 \mathrm{~min}$. Cell pellets were resuspended in $10 \mathrm{mM}$ Tris buffer $(\mathrm{pH} \mathrm{7.5)}$ containing $0.5 \%$ Triton X-100 (Sigma Immunochemicals) and kept at $4^{\circ} \mathrm{C}$ for $1 \mathrm{~h}$. The lysate was centrifuged at $11,000 \mathrm{~g}$ for $20 \mathrm{~min}$ and aliquots of the supernatants were tested for SI activity using sucrose as a substrate as described by Dahlqvist (32). Isolated clones expressing SI were stored in liquid nitrogen.

Fluorescence imaging of intracellular calcium. For fluorescence microscopy, transfected and nontransfected $\mathrm{CHO}$ cells were seeded onto coverslips and allowed to attach and spread for 24-48 h before study. Cells were loaded with fura-2 AM as described previously (33). Cells with visible sequestration of dye into cytoplasmic compartments were excluded. Intracellular calcium was determined by dual fluorescence microscopy on a Zeiss Axiovert inverted microscope equipped for epifluorescence. Calcium concentration was estimated from the following equation: $\mathrm{Ca}^{++}=K_{\mathrm{d}} \times B \times\left(R-R_{\min }\right)\left(R_{\max }-R\right)$; where $K_{\mathrm{d}}$ is equal to $224 \mathrm{nM}$ and B is equal to the ratio of raw fluorescence signals of calcium-free fura-2 at an excitation wavelength of $380 \mathrm{~nm}$ (34). Toxin A or recombinant toxin A peptide was delivered to $\mathrm{CHO}$ cells by pressure ejection through micropipettes (approximate tip diameter $1.0 \mu \mathrm{m}$ ) prepared on a Brown-Flaming Micropipette puller (model P80PC; Sutter Instrument Co., Novato, CA). The micropipette was positioned via a Narashige three-dimensional hydraulic micromanipulator at a magnification of 1,000 and toxin was expelled by the delivery of a 10-psi pulse of nitrogen. Results represent the mean magnitude of calcium response derived only from cells which responded. A significant calcium response to whole or recombinant toxin A was defined as a change in fluorescence which corresponded to $>5 \mathrm{nM}$ cytosolic calcium.

\section{Results}

Purification of the toxin $A B B$ receptor. We purified the toxin A receptor $\sim 160$-fold by a combination of BS-1, toxin A affinity chromatography, and molecular sieve HPLC (Table I). As expected from previous reports $(10,11)$ that the toxin A receptor contained $\alpha$-D-galactose in its ligand binding domain, the majority of the toxin A binding activity was specifically eluted from the BS-1 Sepharose column with $\alpha$-D-galactose providing a 44-fold purification (Table I). Further purification was

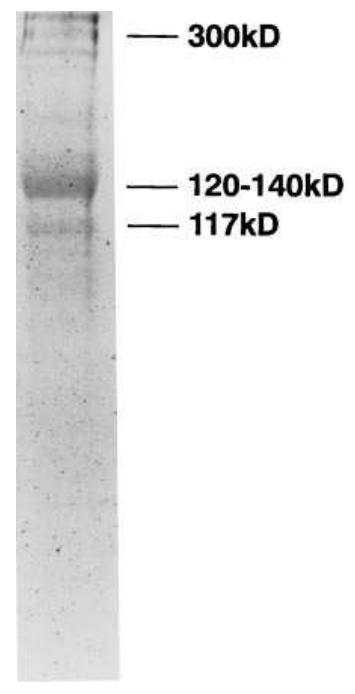

Figure 1. Gel electrophoresis of the toxin A receptor. $10 \mu \mathrm{g}$ of the HPLCpurified receptor (see Methods) was electrophoresed in the presence of SDS according to the method of Laemmli (23). The sample was incubated for $30 \mathrm{~min}$ with 2-mercaptoethanol and $1.25 \%$ SDS and then heated to $100^{\circ} \mathrm{C}$ for $2 \mathrm{~min}$. Electrophoresis was performed on a $1-\mathrm{mm}$ thick $7.5 \%$ acrylamide gel at $200 \mathrm{~V}$ for $45 \mathrm{~min}$. Calculated molecular masses are shown on the right estimated by the migration of molecular mass standards run simultaneously. 


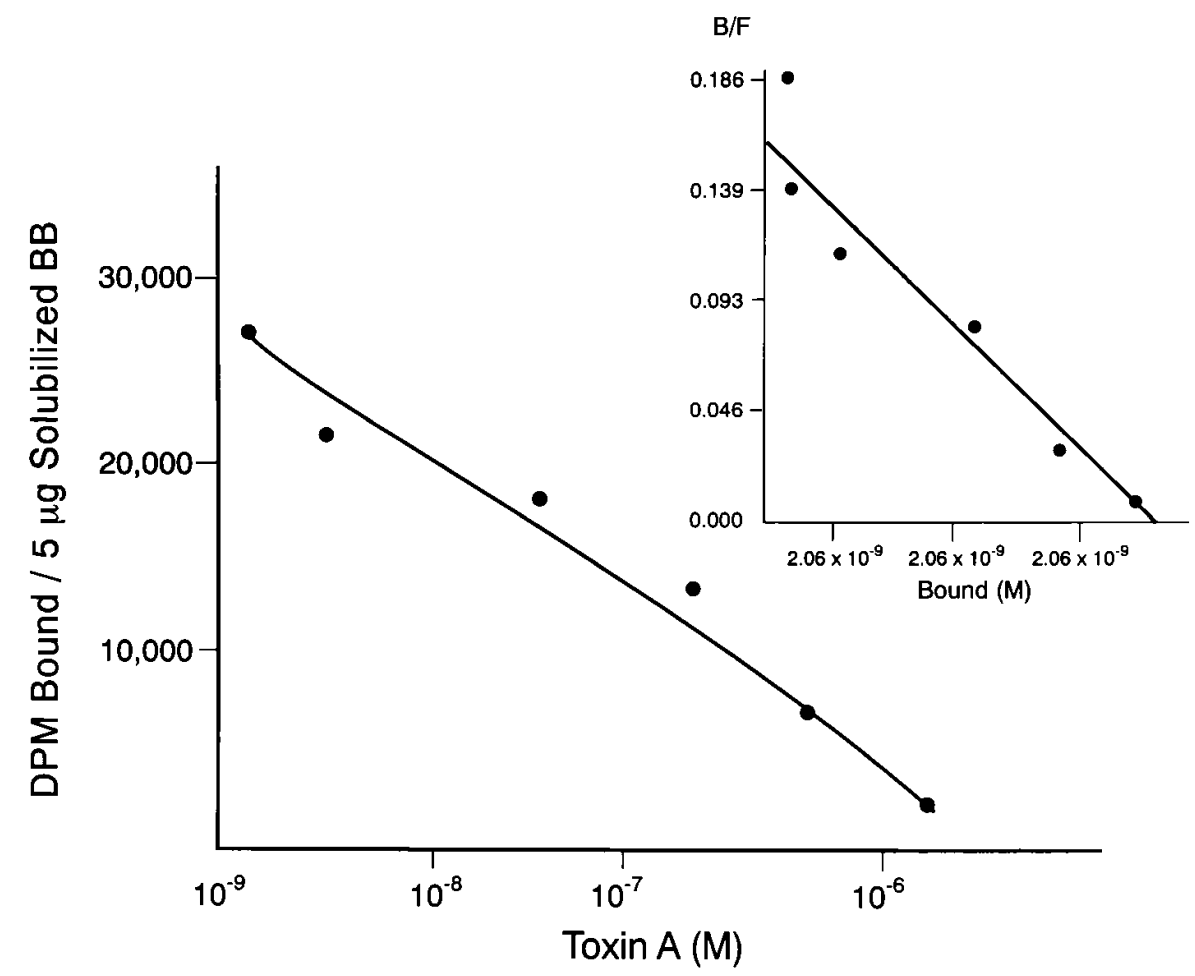

Figure 2. Competitive inhibition of ${ }^{3} \mathrm{H}$-toxin A binding to partially purified toxin A receptor. $5 \mu \mathrm{g}$ of the toxin A affinity partially purified receptor was absorbed to WGA-agarose and then incubated with $66 \mathrm{ng}$ of ${ }^{3} \mathrm{H}$-toxin $\mathrm{A}(190,000$ $\mathrm{dpm})$ and increasing doses of unlabeled toxin A for $60 \mathrm{~min}$ at $22^{\circ} \mathrm{C}$ in $10 \mathrm{mM}$ Tris ( $\mathrm{pH} 7.4$ ) containing $0.2 \%$ CHAPS $(n=3$ per group). The final concentration of ${ }^{3} \mathrm{H}$-toxin A was $1.4 \mathrm{nM}$. Specific binding was determined as described in Methods (Inset) Scatchard plot of binding data. achieved by toxin A-Sepharose affinity chromatography. The majority of bound receptor activity on this column was eluted with $0.5 \mathrm{M} \mathrm{NaCl}$ yielding a further fivefold purification. A 1-ml fraction from the toxin A affinity column containing high ligand binding activity was further purified by HPLC on a G4000 SW molecular sieve column. Most of the toxin A binding activity was eluted as a broad peak in the void volume with the fraction containing the highest binding activity at $7 \mathrm{~min}$. When rechromatographed under identical conditions, fraction 7 migrated as a single peak at $7 \mathrm{~min}$ (not shown) with a purification of $\sim 160$-fold and a yield of $2.9 \%$ (Table I). SDS-PAGE of this fraction revealed a major protein band at $120-140 \mathrm{kD}$, a less prominent band at $117 \mathrm{kD}$, and several minor bands at $\sim 300 \mathrm{kD}$ (Fig. 1).

Binding of ${ }^{3} \mathrm{H}$-toxin A to purified receptor. ${ }^{3} \mathrm{H}$-Toxin A binding to purified $\mathrm{BB}$ receptor was linear between $500 \mathrm{ng}$ and $5 \mu \mathrm{g}$ of $\mathrm{BB}$ protein, saturable at $5 \mu \mathrm{g}$ of solubilized receptor, and maximal at $60 \mathrm{~min}$ (data not shown). As shown in Fig. 2, binding of ${ }^{3} \mathrm{H}$-toxin $\mathrm{A}$ to purified receptor was inhibited by $\sim 50 \%$ in the presence of an 80-fold molar excess of unlabeled toxin A. Based on binding experiments from two separate BB preparations, each derived from five animals, we calculated an apparent $K_{\mathrm{d}}$ of $6 \times 10^{-8} \mathrm{M}$, similar to the $K_{\mathrm{d}}$ of $5.4 \times 10^{-8} \mathrm{M}$ reported earlier for toxin A binding to intact BB (10). Computer analysis of the binding data revealed a best fit to a linear Scatchard plot (Fig. 2, inset) suggesting the presence of a single class of receptors.

Antireceptor IgG inhibits toxin A binding to ileal $B B$. Guinea pigs were immunized with the $120-140-\mathrm{kD}$ protein fraction eluted from polyacrylamide gels of affinity-purified toxin A receptor preparations (Fig. 1). Western blot analysis indicated that antireceptor $\mathrm{IgG}$, but not control IgG, recognized the $120-140-\mathrm{kD}$ BB protein (Fig. 3). Binding of biotinylated toxin $\mathrm{A}$ to rabbit ileal $\mathrm{BB}$ was completely blocked by preincubation of rabbit ileal sections with $100 \mu \mathrm{g} / \mathrm{ml}$ of antire-

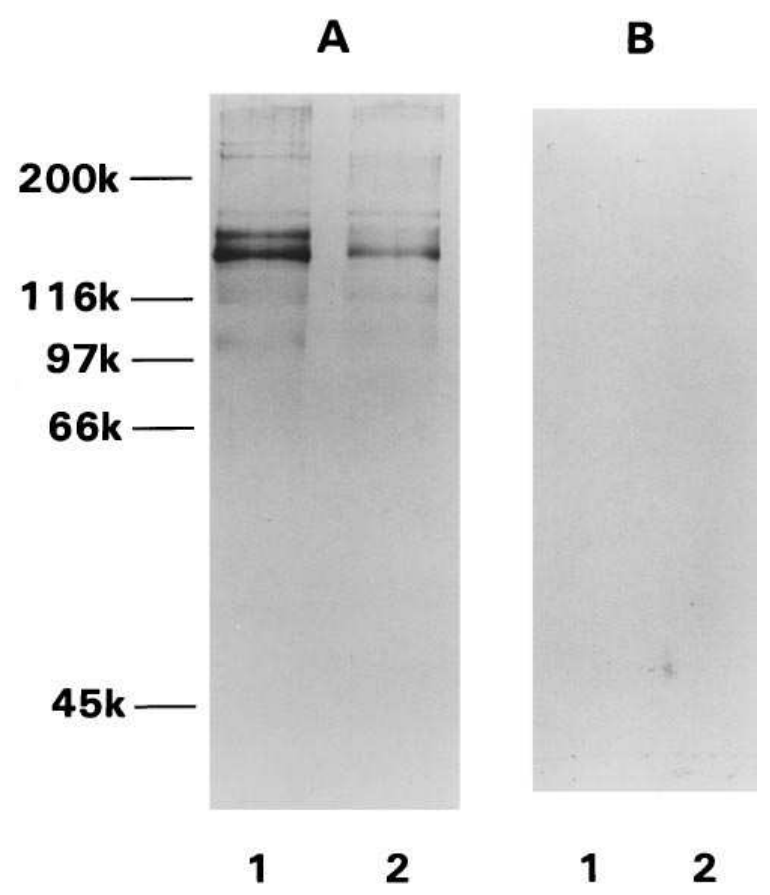

Figure 3. Western blot of the toxin A receptor using antireceptor antibodies. Toxin A receptor $(0.5 \mu \mathrm{g})$ purified from either BS-1 affinity chromatography (lane 1) or toxin A affinity gel (lane 2) was subjected to SDS-PAGE as described in the legend to Fig. 1 and blotted to nitrocellulose sheets. Blots were incubated with anti-toxin A receptor $(A)$ or control IgG $(B)$. Identification of reactive proteins was determined by incubation with anti-guinea pig IgG linked to avidin-alkaline phosphatase as described in Methods. Numbers on the left represent the migration of prestained molecular weight standards: egg albumin $(45 \mathrm{k}$, where $\mathrm{k}$ represents 1,000$)$, bovine serum albumin (66 k), phosphorylase B (97 k), $\beta$-galactosidase (116 k), and myosin (200 k). 

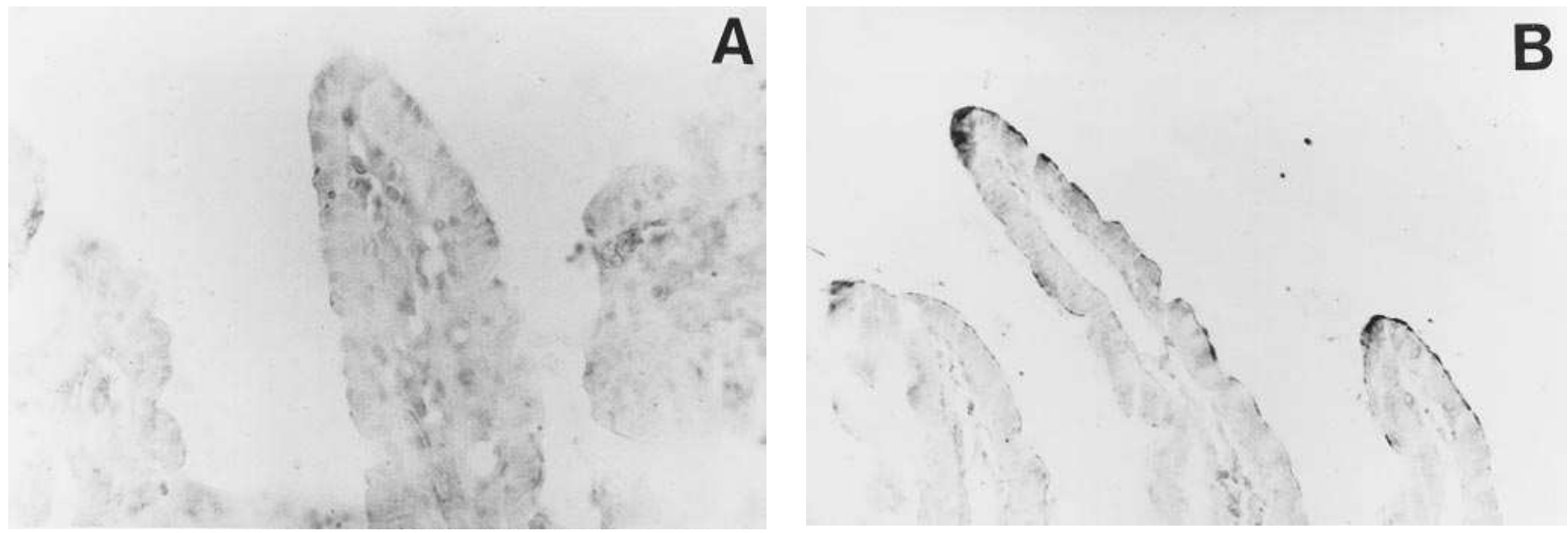

Figure 4. Inhibition of biotinylated-toxin A reactivity by anti-toxin A receptor antibody. Fixed sections of adult rabbit ileum were stained with biotinylated toxin A. Sections were first incubated $\left(1 \mathrm{~h}\right.$ at $\left.37^{\circ} \mathrm{C}\right)$ with either $100 \mu \mathrm{g} / \mathrm{ml}$ of anti-toxin A receptor IgG $(A)$ or $100 \mu \mathrm{g} / \mathrm{ml}$ of control $\operatorname{IgG}(B)$ before staining with biotinylated toxin A.

ceptor IgG (Fig. 4 A). Binding of biotinylated toxin A was clearly seen when control $\mathrm{IgG}$ from vehicle-immunized guinea pig was used (Fig. $4 \mathrm{~B}$ ), giving a staining pattern similar to that seen in the absence of added immunoglobulin (data not shown).

Amino acid sequence of receptor peptides. Two major and several minor peptide peaks were identified by reverse-phase HPLC of a tryptic digest of the 120-140-kD toxin A receptor band (Fig. 1). Amino acid sequences of the two major peptides were: peptide 1: R-Y-E-V-P-H-Q-F-V-T-E-F-A-G-P-A-A-T-E, and peptide 2: T-D-N-P-Y-S-V-S-S-T-Q-Y-S-P-T-G-I-T-A-DL-Q-L-N. Computer-based comparison of these peptide sequences with known proteins revealed that peptide 1 was identical to amino acid residues 169-187 of rabbit SI and peptide 2

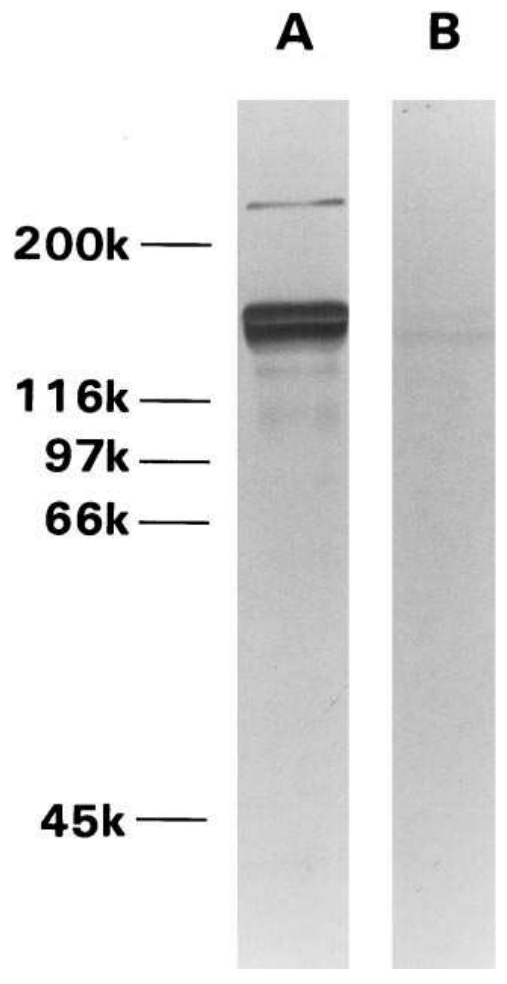

was identical to amino acid residues $979-1001$ of the same protein (26). Moreover, the anti-toxin A receptor antiserum, but not control antiserum, reacted strongly with purified SI (Fig. 5).

Toxin A binding to purified SI. Using the soluble binding assay as described in Methods, we demonstrated that binding of ${ }^{3} \mathrm{H}$-toxin A to purified rabbit SI (Fig. 6) was completely inhibited by a 90 -fold molar excess of unlabeled toxin A (not shown). Removal of $\alpha$-galactose residues from purified SI with $\alpha$-galactosidase significantly inhibited ${ }^{3} \mathrm{H}$-toxin $\mathrm{A}$-specific binding (Fig. 6), indicating that $\alpha$-galactosyl residues on purified SI were probably involved in toxin A binding, as previously reported for the endogenous rabbit $\mathrm{BB}$ receptor $(10,16)$.

Anti-SI antiserum inhibits toxin A enterotoxicity in vivo. Injection of $20 \mu \mathrm{g}$ of purified toxin A into rabbit ileal loops stimulated fluid secretion, caused a 27 -fold increase in bloodto-lumen mannitol permeability (Table II), and caused substantial mucosal injury as determined by histologic score $(3,15$, 17). Each of these effects was significantly inhibited by prein-

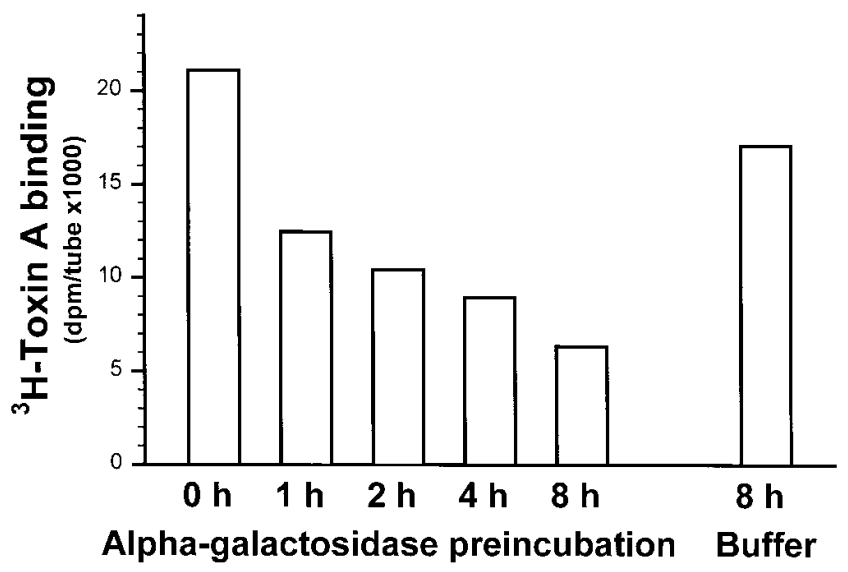

Figure 6. $\alpha$-galactosidase inhibits toxin A-specific binding to rabbit SI. Purified rabbit SI $(5 \mu \mathrm{g})$ was preincubated $\left(37^{\circ} \mathrm{C}\right)$ for the indicated time points with either $10 \mathrm{mM}$ Tris buffer ( $\mathrm{pH} 7.4)$ alone (control) or with buffer containing $0.5 \mathrm{U}$ of $\alpha$-galactosidase. Samples were then absorbed to WGA-agarose and ${ }^{3} \mathrm{H}$-toxin A specific binding was determined as described previously (10). Each data point represents the mean of triplicate determinations. 
Table II. Anti-SI Antiserum Inhibits Toxin A-mediated Secretion and Mannitol Permeability

\begin{tabular}{lccc}
\hline & Fluid secretion & $\begin{array}{c}\text { 3H-Mannitol } \\
\text { permeability }\end{array}$ & Histologic score \\
\hline & $m g / c m$ & $d p m / c m$ loop & \\
& $400 \pm 20$ & $2300 \pm 880$ & $0.75 \pm 0.25$ \\
Buffer & $984 \pm 81^{*}$ & $58780 \pm 6400 *$ & $6.40 \pm 0.49 *$ \\
Toxin A & $564 \pm 35^{* *}$ & $13280 \pm 3600 * \neq$ & $3.39 \pm 0.60 * \ddagger$ \\
Toxin A + anti-SI IgG & $955 \pm 115^{*}$ & $43630 \pm 6300^{*}$ & $7.8 \pm 0.58^{*}$ \\
Toxin A + control IgG & & & \\
& & &
\end{tabular}

Rabbit ileal loops were injected with $1 \mathrm{ml}$ either buffer or buffer containing $1 \mathrm{mg}$ of anti-SI antiserum or control guinea pig antiserum $15 \mathrm{~min}$ before administration of $20 \mathrm{mg}$ of toxin A or buffer into the loops $(n=$ 12 per group). After $5 \mathrm{~h}$, loops were excised and fluid secretion was measured by loop weight $(\mathrm{mg}) /$ length $(\mathrm{cm})$ ratio. Intestinal permeability to ${ }^{3} \mathrm{H}$-mannitol was estimated by scintillation counting of aliquots of loop samples. Histologic score was determined in five to eight loops per group as described in Methods. Results are expressed as mean \pm SE. $* P<0.01$ vs. buffer, and ${ }^{\ddagger} P<0.01$ vs. toxin A alone.

jection of the loops with anti-SI antiserum (1 mg/loop). Control guinea pig antiserum had no statistically significant effects.

Transfection of CHO cells with rabbit SI cDNA. Exposure of target cells to toxins $\mathrm{A}$ and $\mathrm{B}$ is followed by a nearly immediate rise in intracellular calcium $(33,35)$. This rise in calcium was used to assess toxin A binding to SI in CHO cells transfected with rabbit SI cDNA. CHO cells transfected with rabbit SI cDNA contained SI mRNA and protein by Northern blot analysis, as well as SI enzymatic activity, whereas no SI activity was detected in untransfected $\mathrm{CHO}$ cells (Fig. 7). As shown in Fig. 8 (left) exposure of wild-type $\mathrm{CHO}$ cells to toxin A (holotoxin) or recombinant toxin $\mathrm{A}$ receptor binding peptide caused calcium elevations in 6.2 and $11.8 \%$ of cells, respectively. However, when $\mathrm{CHO}$ cells transfected with rabbit SI cDNA were exposed to holotoxin or a recombinant toxin A receptor binding domain, the percentage of cells exhibiting an increase in intracellular calcium was 66.7 and 69.2, respectively $(P<0.01)$. Response amplitude of the calcium signal in SItransfected cells was increased by approximately twofold compared with untransfected $\mathrm{CHO}$ cells (Fig. 8, right).

\section{Discussion}

We report here that the $\mathrm{BB}$ exoenzyme SI specifically binds toxin A of $C$. difficile with a $K_{\mathrm{d}}$ similar to those reported previously for rabbit BB membranes (10). Additionally, we provide evidence that binding of toxin A to CHO cells expressing SI elicits a rise in intracellular calcium and that $\mathrm{IgG}$ antibody to SI partially blocks enterotoxicity in rabbit ileum in vivo (Table II). We conclude from these observations that SI contains a functional receptor for toxin A on rabbit enterocytes.

The SI complex, an intrinsic BB disaccharidase expressed almost exclusively on the luminal surface of small intestinal villus enterocytes $(36,37)$, is synthesized as a $260-\mathrm{kD}$ precursor (pro SI) that is split by pancreatic proteases into two subunits, isomaltase $(\sim 140 \mathrm{kD})$ and sucrase $(\sim 120 \mathrm{kD})$, that are noncovalently linked. SI has five functional/structural domains. The enzymes sucrase and isomaltase are attached by a short connecting segment or stalk to the outer leaflet of the entero-

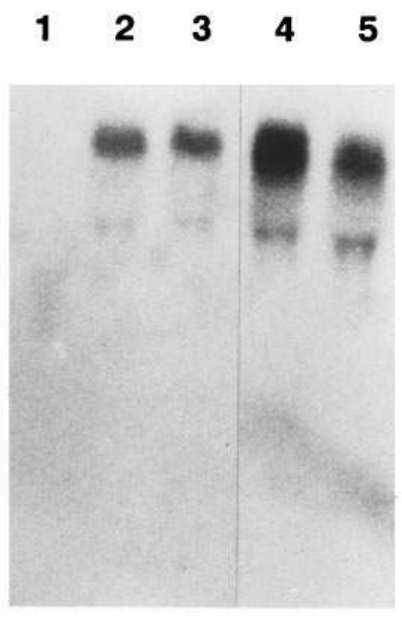

Figure 7. (Top) Northern blot analysis of RNA isolated from different permanent $\mathrm{CHO}$ cell lines expressing SI mRNA. Lane 1 contains RNA from nontransfected $\mathrm{CHO}$ cells and lanes $2-5$ contain RNA from transfected $\mathrm{CHO}$ cells. All lanes contain $10 \mu \mathrm{g}$ of RNA. (Bottom) SI enzymatic activity of nontransfected (lane 1) and SI-transfected $\mathrm{CHO}$ cells (lanes 2-5) measured by the method of Dahlqvist (32, see Methods for details).

cyte BB. A hydrophobic transmembrane segment spans the lipid bilayer and a short cytoplasmic domain of 12 amino acids extends into the cytoplasm (26). The solubilized SI heterodimer produces two patterns on SDS-PAGE; a 120-140$\mathrm{kD}$ doublet (as in Fig. 3), or, more frequently, a broad band (similar to the major band in Fig. 1). The latter is generated when the amino-terminal stalk of the isomaltase subunit is proteolytically cleaved (37). Because toxin A binding to SI was dramatically inhibited by enzymatic removal of $\alpha$-galactose residues (Fig. 6), we conclude that toxin A binds to a terminal $\alpha$-galactose residue on one or more of the potential extracellular glycosylation sites on SI. Our data do not exclude the possibility that other BB glycoproteins bearing the same trisaccharide might also function as toxin A receptors. Antibody to SI significantly inhibited toxin A secretion, permeability, and mucosal injury (Table II) but inhibition was not complete. This raises the possibility that membrane glycoproteins other than SI can bind the toxin, perhaps via the same trisaccharide group proposed to bind toxin A on SI.

Occupancy of the toxin A receptor in human neutrophils is associated with a rapid rise in intracellular calcium that can be inhibited by pretreatment of these cells with pertussis toxin (35). These findings are typically associated with membrane receptors belonging to the large class of G-protein-associated receptors with seven membrane-spanning domains, a family of proteins whose structure is unrelated to SI. However, SI does have certain structural features in common with a second family of G-protein-associated receptors with single spanning transmembrane domains (38-40). An interesting member of this family of receptors is the sperm receptor protein $\beta-1,4$ ga- 


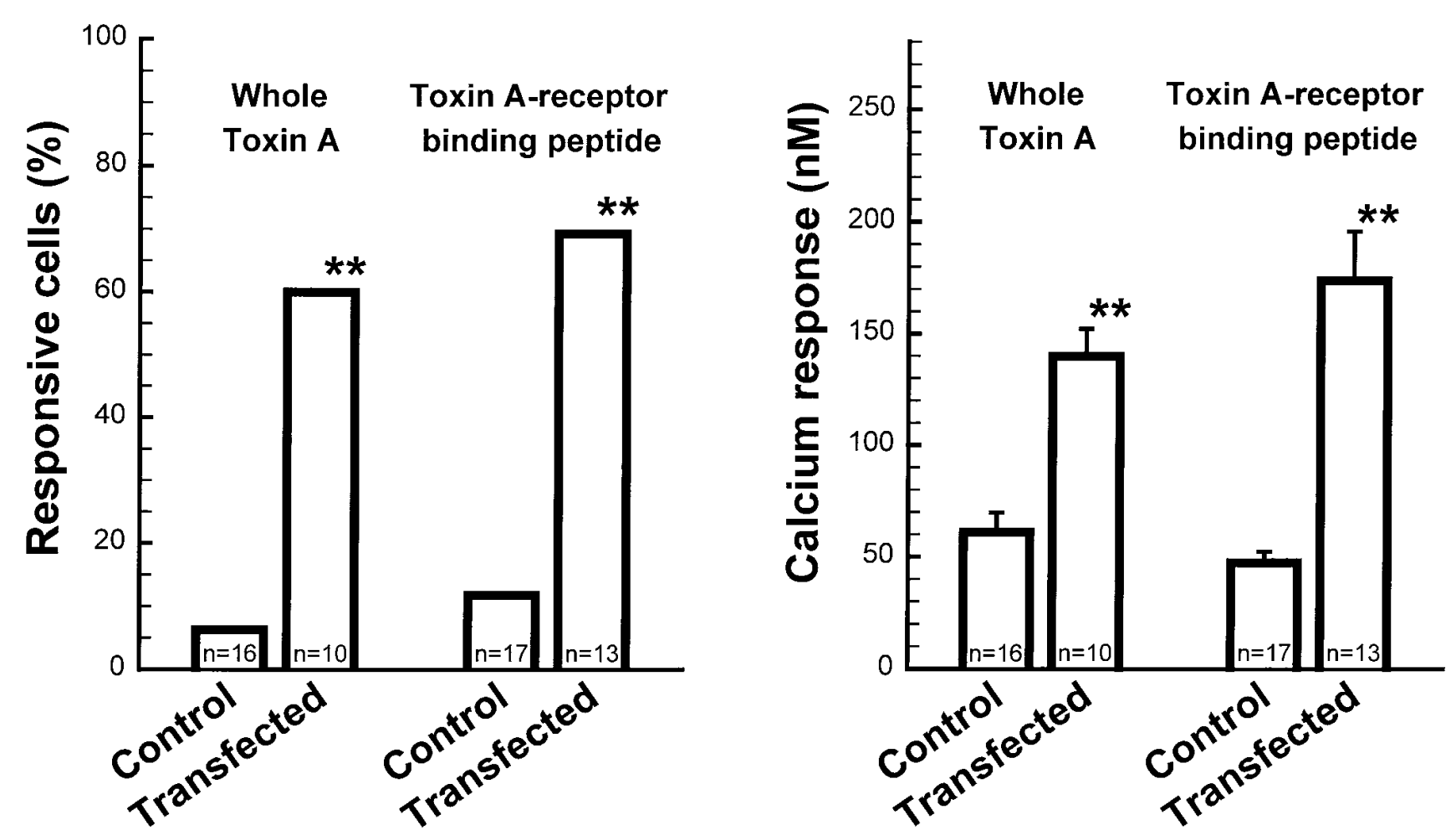

Figure 8. Effect of toxin A (holotoxin) and of recombinant toxin A binding peptide on intracellular calcium responses of CHO cells transfected with SI cDNA. Untransfected and SI-transfected $\mathrm{CHO}$ cells were loaded with fura-2 and imaged for intracellular calcium by fluorescence microscopy. Holotoxin or toxin A binding peptide was delivered by pressure ejection adjacent to the cell membrane. A significant calcium response to whole or recombinant toxin was defined as a change of fluorescence which corresponded to $>5 \mathrm{nM}$ cytosolic calcium. (Left) Percentage of cells which were responsive (number of cells demonstrating calcium response/number of cells exposed to holotoxin or toxin A binding peptide). (Right) Amplitude of intracellular calcium response, represented as a change of intracellular calcium concentration (nM). Results represent the mean per group. $n$ indicates the number of cells studied. $* * P<0.01$ vs. control nontransfected cells.

lactosyltransferase which binds O-linked oligosaccharides on the glycoprotein ZP3 on the egg zona pellucida (41). Binding induces a signal transduction cascade culminating in the acrosome reaction that allows the sperm to penetrate the zona pellucida. The cytoplasmic domain of sperm galactosyltransferase consists of a 24-amino acid peptide with serine and threonine residues that are phosphorylated in response to ligand binding (41). Recently the 12-amino acid cytoplasmic domain of SI was shown to contain a serine at position 6 that can be phosphorylated by protein kinase A in vivo and in vitro (42). The physiologic significance of SI phosphorylation is not known, but these observations raise the possibility that toxin $\mathrm{A}$ binding to SI on the BB membrane may trigger phosphorylation of serine 6 in the cytoplasmic domain that in turn enhances its interaction with heterotrimeric G-proteins.

A major function of toxin receptors is to facilitate the entry of these large proteins into target cells. Our data do not allow us to speculate how the SI-toxin A complex is internalized. However, aminopeptidase $\mathrm{N}$, another intestinal BB exoenzyme, was shown recently to be a major receptor for transmissible gastroenteritis virus, a pathogenic corona virus in newborn pigs (43). Like SI, aminopeptidase $\mathrm{N}$ is highly expressed in mature villus enterocytes and lacks structural homology with other viral receptors or with seven membrane-spanning domain receptors. Intestinal damage from this virus in piglets is highly correlated with the tissue distribution of aminopeptidase N (43). Similarly, certain biologic effects of toxin A corre- late with the known intestinal distribution of SI $(36,44)$. We reported earlier that biotinylated toxin A bound exclusively to rabbit villus cells but not to crypts (16). Moreover, exposure of rat small intestine to toxin A results predominantly in villus cell damage and sparing of crypts (45). Finally the lack of toxin A binding observed in newborn rabbit ileum (16) is consistent with the lack of expression of SI on small intestinal villus cells in infant rabbits (46).

Our data indicate that the catalytic portion of toxin A that possesses glucosyltransferase activity for rho proteins (47) is not required for binding to or activation of the receptor. $\mathrm{Re}$ combinant toxin A binding domain was able to elicit a threefold increase in intracellular calcium in $\mathrm{CHO}$ cells transfected with rabbit SI (Fig. 8), indicating that modification of Rho is not required for this effect. This ability of toxin A recombinant peptide to activate a receptor-mediated cascade finds parallel in other microbial receptor-ligand systems. For example, the binding subunit of pertussis toxin is a potent mitogen for $\mathrm{T}$ lymphocytes (48). Adenovirus attachment of mammalian cells is mediated by a $400-\mathrm{kD}$ protein pentamer, the penton base. Cells exposed to soluble penton base undergo morphologic changes similar to cells exposed to whole virus (49), an effect mediated by binding of the penton base to cell surface integrin receptors $(50)$.

The tissue distribution of SI is limited to the small intestine. Thus, our demonstration here that SI is a major binding protein for toxin $\mathrm{A}$ in rabbit ileum cannot explain the ability of 
toxin A to cause damage in other cells or organs. Rat, rabbit, and human colon as well as fibroblasts, monocytes, and neutrophils are quite sensitive to toxin A $(2,10,15,35,45,51,52)$, yet none expresses SI. Binding of toxin to these cells apparently involves other glycoproteins or glycolipids with the appropriate glycosyl residues required for binding. Moreover, the trisaccharide $\mathrm{Gal}_{1-3} \mathrm{Gal}_{1-4} \mathrm{GlcNAc}$ mediates toxin A binding in rodents, but this trisaccharide is not expressed in human cells because they lack the appropriate $\alpha$-galactosyltransferase (53). We conclude from our observations that different receptors with various carbohydrate prosthetic groups can function as toxin A binding proteins in various cells. In support of this, Tucker and Wilkins (54) reported that the purified carbohydrate antigens I, X, and Y expressed on various human epithelial cells are capable of binding toxin A.

In conclusion, the rabbit small intestinal $\mathrm{BB}$ membrane enzyme SI contains specific binding sites for $C$. difficile toxin A. Our data suggest that SI is the major toxin A binding site in rabbit ileum, but we cannot exclude the possibility of additional binding sites. Binding of toxin to $\alpha$-galactosyl residues on this enzyme produces biologic effects in the ileum and in $\mathrm{CHO}$ cells expressing rabbit SI. Toxin A binding to carbohydrates on SI is analogous to the binding of cholera toxin to the BB glycolipid monosialoganglioside (GM1) (55), or the binding of thyroid-stimulating hormone to its glycoprotein receptor via an $\alpha$-galactose-containing trisaccharide (56). Given the limited tissue expression of SI, it appears likely that multiple glycoproteins or glycolipids can serve as toxin A receptors, with considerable organ and species specificity. Our studies should allow further elucidation of the signal transduction processes, particularly calcium mobilization and G-protein activation, that follow binding of $C$. difficile toxin A to its receptor.

\section{Acknowledgments}

This work is dedicated to the memory of our colleague and friend, Christos Cladaras, Ph.D., who died in August 1994.

The authors acknowledge support from the National Institutes of Health (grants DK-34583 to J.T. LaMont, DK-47343 to C. Pothoulakis, and DK-02128 to Ciaran P. Kelly), and from the Crohn's and Colitis Foundation of America (C. Pothoulakis and I. Castagliuolo).

\section{References}

1. Kelly, P.C., C. Pothoulakis, and J.T. LaMont. 1994. Clostridium difficile colitis. N. Engl. J. Med. 330:257-262.

2. Mitchell, T.J., M. Ketley, S.C. Haslam, D.W. Stephen, D.C. Burton, A. Candy, and R. Daniel. 1986. Effect of toxins A and B of Clostridium difficile on rabbit ileum and colon. Gut. 27:78-85.

3. Triadafilopoulos, G., C. Pothoulakis, M.J. O'Brian, and J.T. LaMont. 1987. Differential effects of Clostridium difficile toxins A and B on rabbit ileum. Gastroenterology. 93:273-279.

4. Lima, A.A.M., D.M. Lyerly, T.D. Wilkins, D.J. Innes, and R.L. Guerrant. 1988. Effects of Clostridium difficile toxins A and B in rabbit small and large intestine in vivo and on cultured cells in vitro. Infect. Immun. 56:582-588.

5. Dove, C., S.-Z. Wang, S.B. Price, C.J. Phelps, D.M. Lyerly, T.D. Wilkins, and J.L. Johnson. 1990. Molecular characterization of the Clostridium difficile toxin A gene. Infect. Immun. 58:480-488.

6. Just, I., J. Selzer, C. Von Eichel-Striber, and K. Aktories. 1995. The low molecular mass GTP-binding protein Rho is affected by toxin A from Clostridium difficile. J. Clin. Invest. 95:1026-1031.

7. Dillon, S.T., E. Rubbin, M. Yakubovich, C. Pothoulakis, J.T. LaMont, L.A. Feig, and R.J. Gilbert. 1995. Involvement of Ras-related Rho proteins in the mechanisms of action of Clostridium difficile toxin A and B. Infect. Immun. 63:1421-1426.

8. Corthier, G., M.C. Muller, T.D. Wilkins, D.M. Lyerly, and R.L. Haridon. 1991. Protection against experimental pseudomembranous enterocolitis in gno- tobiotic mice by use of monoclonal antibodies against Clostridium difficile toxin A. Infect. Immun. 59:1192-1195.

9. Lyerly, D.M., J.L. Johnson, S.M. Frey, and T.D. Wilkins. 1990. Vaccination against lethal Clostridium difficile enterocolitis with a nontoxic recombinant peptide of toxin A. Curr. Microbiol. 21:29-32.

10. Pothoulakis, C., J.T. LaMont, R. Eglow, N. Gao, J.B. Rubins, T.C Theoharides, and B.F. Dickey. 1991. Characterization of rabbit ileal receptors for Clostridium difficile toxin A. Evidence for a receptor-coupled G pathway. $J$. Clin. Invest. 88:119-125.

11. Krivan, H., C.F. Klark, D.F. Smith, and T.D. Wilkins. 1986. Cell surface binding site for Clostridium difficile enterotoxin: evidence for a glycoconjugate containing the sequence Gal $\alpha 1-3 \mathrm{Gal} \beta 1-4 \mathrm{GlcN} A c$. Infect. Immun. 53:573-581.

12. Rolfe, R.D., and W. Song. 1993. Purification of a functional receptor for Clostridium difficile toxin A from intestinal brush border membranes of infant hamsters. Clin. Infect. Dis. 16(Suppl. 4):S219-S227.

13. Pothoulakis, C., N. Gao, P. Dudeja, J. Haring, T.A. Brasitus, and J.T. LaMont. 1992. The human Clostridium difficile toxin A receptor is a trypsin sensitive glycoprotein. Gastroenterology. 102:680a. (Abstr.)

14. Clark, G.F., N.C. Krivan, T.D. Wilkins, and B.F. Smith. 1987. Toxin A from Clostridium difficile binds to rabbit erythrocyte glycolipids with terminal Gal $\alpha_{1-3} \mathrm{Gal}_{1-4}$ GlcNAc sequences. Arch. Biochem. Biophys. 257:217-229.

15. Kelly, C.P., S.D. Becker, J. Linevsky, M.A. Joshi, J.C. O'Keane, B.F. Dickey, J.T. LaMont, and C. Pothoulakis. 1994. Neutrophil recruitment in Clostridium difficile toxin A enteritis. J. Clin. Invest. 93:1257-1265.

16. Eglow, R., C. Pothoulakis, S. Itzkowitz, E.J. Israel, C.J. O'Keane, D. Gong, N. Gao, Y.L. Xu, W.A. Walker, and J.T. LaMont. 1992. Diminished Clostridium difficile toxin A sensitivity in newborn rabbit is associated with decreased toxin A receptor. J. Clin. Invest. 90:822-829.

17. Triadafilopoulos, G., C. Pothoulakis, R. Weiss, C. Giampaolo, and J.T LaMont. 1987. Comparative study of Clostridium difficile toxin A and cholera toxin in rabbit ileum. Role of prostaglandins and leukotrienes. Gastroenterology. 92:1174-1180.

18. Pothoulakis, C., F. Karmeli, C.P. Kelly, R. Eliakin, M.A. Joshi, J.C O'Keane, J.T. LaMont, and D. Rachmilewitz. 1993. Mast cell involvement in Clostridium difficile toxin A enteritis in rat. Studies with ketotifen. Gastroenterology. 105:701-707.

19. Pothoulakis, C., I. Castagliuolo, J.T. LaMont, A. Jaffer, J.C. O'Keane, R.M. Snider, and S.E. Leeman. 1994. CP-96,345, a substance P antagonist, inhibits rat intestinal responses to Clostridium difficile toxin A but not cholera toxin. Proc. Natl. Acad. Sci. USA. 91:947-951.

20. Castagliuolo, I., J.T. LaMont, R. Letourneau, C.P. Kelly, J.C. O’Keane, A. Jaffer, T.C. Theoharides, and C. Pothoulakis. 1994. Neuronal involvement in the intestinal effects of Clostridium difficile toxin A and Vibrio cholera enterotoxin in rat ileum. Gastroenterology. 107:657-665.

21. Phelps, C.J., D.M. Lyerly, T.D. Johnson, and T.D. Wilkins. 1990. Construction and expression of the complete Clostridium difficile toxin A gene in Escherichia coli. Infect. Immun. 59:150-153.

22. Maniatis, T., E.F. Fritsch, and J. Sambrook. 1989. Molecular Cloning: A Laboratory Manual. Cold Spring Harbor Laboratory, Cold Spring Harbor, NY. 23. Laemmli, U.K. 1970. Cleavage of structural proteins during the assembly of the head of bacteriophage $\mathrm{T}_{4}$. Nature (Lond.). 227:680-685.

24. Frey, S.M., and T.D. Wilkins. 1992. Localization of two epitopes recognized by monoclonal antibody PCG-4 on Clostridium difficile toxin A. Infect. Immun. 60:2488-2492.

25. Munson, P. 1983. A computerized analysis of ligand binding data. Methods Enzymol. 92:543-576.

26. Hunziker, W., M. Spiess, G. Semenza, and H.F. Lodish. 1986. The sucrase-isomaltase complex: primary structure, membrane-orientation, and evolution of a stalked, intrinsic brush border protein. Cell. 46:227-234.

27. Graham, F.J., and A. Van der Eb. 1973. A new technique for the assay of infectivity of human adenovirus 5 DNA. Virology. 52:456-460.

28. Blochlinger, K., and H. Diggelmann. 1984. Hygromycin B phosphotransferase as a selectable marker for DNA transfer experiments with higher eukaryotic cells. Mol. Cell. Biol. 4:2929-2931.

29. Bernard, U.H., G. Kramer, and W.G. Rowekamp. 1985. Construction of a fusion gene that confers resistance against hygromycin B to mammalian cells in culture. Exp. Cell Res. 158:237-243.

30. Kaster, K.R., S.G. Burgett, R.N. Rao, and T.D. Ingolia. 1983. Analysis of a bacterial hygromycin B resistance gene by transcriptional and translational fusions and by DNA sequencing. Nucleic Acids Res. 11:6895-6911.

31. Chomczynski, P., and N. Sacchi. 1987. Single-step method for RNA isolation by acid guanidinium thiocyanate-phenol-chloroform extraction. Anal. Biochem. 162:156-159.

32. Dahlqvist, A. 1964. Method for assay of intestinal disaccharidases. Anal. Biochem. 7:18-25.

33. Gilbert, R.J., C. Pothoulakis, J.T. LaMont, and M. Yakubovich. 1995. Clostridium difficile toxin B activates calcium influx which is required for actin disassembly during cytotoxicity. Am. J. Physiol. 268:G487-G495.

34. Grynkiewicz, G., M. Poinie, and R.Y. Tsien. 1985. A new generation of $\mathrm{Ca}^{++}$indicators with greatly improved fluorescence properties. J. Biol. Chem. 260:3440-3450.

35. Pothoulakis, C., R. Sullivan, D.A. Melnick, A.S. Gadenne, T. Meshulan, 
and J.T. LaMont. 1988. Clostridium difficile toxin A stimulates intracellular calcium release and chemotactic response in human neutrophils. J. Clin. Invest. 81: 1741-1745.

36. Traber, P.G. 1990. Regulation of sucrase-isomaltase gene expression along the crypt-villus axis of rat small intestine. Biochem. Biophys. Res. Commun. 173:765-773.

37. Brunner, J., H. Hauser, H. Braun, K.J. Wilson, H. Wacker, B. O'Neill, and G. Semenza. 1979. The mode of association of the enzyme complex sucrase-isomaltase with the intestinal brush border membrane. J. Biol. Chem. 254: 1821-1828.

38. Luttrell, L., E. Kilgour, J. Larner, and G. Romero. 1990. A pertussis toxin-sensitive G-protein mediates some aspects of insulin action in $\mathrm{BC} 3 \mathrm{H}-1$ murine myocytes. J. Biol. Chem. 265:16873-16879.

39. Sun, H., J.M. Seyer, and T.B. Patel. 1995. A region in the cytosolic domain of the epidermal growth factor receptor antithetically regulates the stimulatory and inhibitory guanine nucleotide-binding regulatory proteins of adenylyl cyclase. Proc. Natl. Acad. Sci. USA. 92:2229-2233.

40. Nishimoto, I., T. Okamoto, Y. Matsura, S. Takahashi, T. Okamoto, Y. Murayama, and E. Ogata. 1993. Alzheimer amyloid protein precursor complexes with brain GTP-binding protein Go. Nature (Lond.). 362:75-77.

41. Gong, X., D.H. Dubois, D.J. Miller, and B.D. Shur. 1995. Activation of a $\mathrm{G}$ protein complex by aggregation of $\beta$-1,4-galactosyltransferase of the surface of the sperm. Science (Wash. DC). 269:1718-1721.

42. Keller, P., G. Semenza, and S. Shaltiel. 1995. Phosphorylation of the $\mathrm{N}$-terminal intracellular tail of sucrase-isomaltase by cAMP-dependent protein kinase. Eur. J. Biochem. 233:963-968.

43. Delmas, B., J. Gelfi, R. L'Haridon, L.K. Vogel, H. Sjostrom, O. Noren, and H. Laude. 1992. Aminopeptidase $\mathrm{N}$ is a major receptor for the enteropathogenic coronavirus TGEV. Nature (Lond.). 357:417-420.

44. Traber, P.G., Y. Lai, G.D. Wu, and T.A. Judge. 1992. Sucrase-isomaltase gene expression along the crypt-villus axis of human small intestine is regulated at level of mRNA abundance. Am. J. Physiol. 262(Gastrointest. Liver Physiol. 25):G123-G130.

45. Torres, J., E. Jennische, S. Lang, and I. Lonnroth. 1990. Enterotoxins from Clostridium difficile; diarrhoeogenic potency and morphological effects in the rat intestine. Gut. 31:781-785.

46. Dubs, R., R. Gitzelmann, B. Steinmann, and J. Lindermann. 1975. Catalytically inactive sucrase antigen of rabbit small intestine: the enzyme precursor. Helv. Paediatr. Acta. 30:89-102.

47. Just, I., M. Wilm, J. Selzer, G. Rex, C. Von Eichel-Streiber, M. Mann, and K. Aktories. 1995. The enterotoxin from C. difficile (ToxA) monoglucosylates the Rho proteins. J. Biol. Chem. 270:13932-13936.

48. Tamura, M., K. Nogimory, M. Yajima, K. Ase, and M. Ui. 1983. A role of the B-oligomer moiety of islet activating protein, pertussis toxin, in development of the biologic effects on intact cells. J. Biol. Chem. 258:6756-6761.

49. Pereira, H.G. 1958. A protein factor responsible for the early cytopathic effect of adenoviruses. Virology. 6:601-611.

50. Bergelson, J.M., and R.W. Finberg. 1993. Integrins as receptors for virus attachment and cell entry. Trends Microbiol. 1:287-288.

51. Flegel, W.A., F. Muller, W. Daubener, H.-G. Fisher, U. Hadding, and H. Northoff. 1991. Cytokine response by human monocytes to Clostridium difficile toxin A and B. Infect. Immun. 59:3659-3666.

52. Riegler, M., R. Sedivy, C. Pothoulakis, G. Hamilton, J. Zachert, G. Bischof, E. Consentini, W. Feil, R. Schiessel, J.T. LaMont, and E. Wenzl. 1995. Clostridium difficile toxin $\mathrm{B}$ is more potent than toxin $\mathrm{A}$ in damaging human colonic epithelium in vitro. J. Clin. Invest. 95:2004-2011.

53. Thall, A., J. Etienne-Decerf, R. Winand, and U. Galili. 1991. The $\alpha$-galactosyl epitope on mammalian thyroid cells. Acta Endocrinol. 124:692-699.

54. Tucker, K.T., and T.D. Wilkins. 1991. Toxin A of Clostridium difficile binds to the human carbohydrate antigens I, X, and Y. Infect. Immun. 59:73-78.

55. Critchley, D.R., J.L. Magnani, and P.H. Fishman. 1981. Interaction of cholera toxin with rat intestinal brush border membranes. J. Biol. Chem. 256: 8724-8731.

56. Winand, R.J., F. Anaraki, J. Etienne-Decerf, and U. Galili. 1993. Xenogenic thyroid-stimulating hormone-like activity of the human anti-Gal antibody. Interaction of anti-Gal with porcine thyrocytes and with recombinant human thyroid-stimulating hormone receptors expressed on mouse cells. $J$. Immunol. 151:3923-3934. 